\title{
Kepemimpinan Kepala Madrasah Dalam Meningkatkan Kinerja Guru Di Mi Nw 02 Kembang Kerang Kecamatan Aikmel Lombok Timur
}

\author{
Yuni Yulianti ${ }^{1}$, Sri Harmonika², Fizian Yahya ${ }^{3}$ \\ ${ }^{1}$ yuliantiyuni@gmail.com, ${ }^{2}$ sriharmonika847@ gmail.com , 2 fizian1989@gmail.com \\ ${ }^{123}$ Manajemen Pendidikan Islam, STAI Darul Kamal, Lombok Timur, Indonesia
}

\begin{abstract}
Abstrak
Penelitian ini bertujuan untuk mengetahui kepemimpinan kepala madrasah dalam meningkatkan kinerja guru di MI NW 02 Kembang Kerang serta faktor pendukung dan penghambat kepemimpinan kepala madrasah dalam meningkatkan kinerja guru di MI NW 02 Kembang Kerang. Penelitian ini merupakan penelitian kualitatif yang dilakukan untuk mengungkapkan berbagai gejala yang muncul dari berbagai pola kepemimpinan kepala madrasah terhadap kinerja guru di MI NW 02 Kembang Kerang. Adapun metode yang digunakan dalam pengumpulan data antara lain; metode observasi, metode wawancara dan metode dokumentasi. Setelah data terkumpul selanjutnya dianalisis menggunakan metode analisis data deskriptif dengan proses reduksi data, penyajian data, dan penarikan kesimpulan. Berdasarkan pada hasil penelitian dan pembahasan tentang kepemimpinan kepala madrasah dalam meningkatkan kinerja guru di MI NW 02 Kembang Kerang, maka dapat diambil kesimpulan sebagai berikut: 1) Kepala madrasah dalam meningkatkan kinerja guru di MI NW 02 Kembang Kerang telah melakukan beberapa upaya, antara lain; a. menanamkan sikap disiplin, b. pembinaan dan supervisi, c. meningkatkan sumber daya dan profesionalisme guru, d. memberikan motivasi, dan e. menyediakan fasilitas yang memadai bagi guru. 2) Faktor pendukung kepemimpinan kepala madrasah dalam meningkatkan kinerja guru di MI NW 02 Kembang Kerang, meliputi; a. hubungan yang harmonis antara kepal madrasah dan guru, b. adanya motivasi yang kuat dari guru, dan c. tingkat pendidikan yang memadai. Sedangkan yang menjadi faktor penghambat bagi kepemimpinan kepala madrasah dalam meningkatkan kinerja guru di MI NW 02 Kembang Kerang meliputi; a. kurangnya sarana dan prasarana belajar, dan b. tempat tinggal guru dan siswa yang jauh dari madrasah.
\end{abstract}

Kata Kunci : Kepemimpinan, Kepala Madrasah, Kinerja Guru.

\section{Pendahuluan}

Keberhasilan pendidikan identik dengan keberhasilan kepala madrasah. ${ }^{1}$ Kepala madrasah sebagai manajer mempunyai peran yang menentukan dalam pengelolaan hal. 81

${ }^{1}$ Wahjosumidjo, Kepemimpinan Kepala Sekolah, (Jakarta: Raja Grafindo Persada 2007), 
manajemen sekolah, berhasil tidaknya tujuan sekolah dapat dipengaruhi bagaimana kepala sekolah menjalankan fungsi-fungsi manajemen. Fungsi-fungsi manajemen tersebut adalah planning (perencanaan), organizing (pengorganisasian), actuating (penggerakan), dan controlling (pengontrol). ${ }^{2}$ Dengan wewenang dan kekuasaan, serta kompetensi yang dimiliki kepala sekolah harus mampu mengatur dan mengembangkan bawahannya secara profesional. Dengan demikian kepala madrasah harus memiliki kompetensi profesional yaitu: (1) kepala madrasah sebagai pemimpin, (2) kepala madrasah sebagai manajer, (3) kepala madrasah sebagai pendidik, (4) kepala madrasah sebagai administrator, (5) kepala madrasah sebagai wirausahawan, (6) kepala madrasah sebagai pencipta iklim kerja, dan (7) kepala madrasah sebagai penyelidik. ${ }^{3}$

Melihat besarnya peranan kepala madrasah dalam suatu lembaga pendidikan, maka mutu lembaga pendidikan akan sangat ditentukan oleh sejauhmana kepala sekolah berhasil menerapkan dan menjalankan fungsinya berdasarkan aturan dan standar pengelolaan yang baik. Keberhasilan kepala sekolah menjalankan peranya sebagai pendidik dan sebagai pencipta iklim kerja yang baik akan meningkatkan kinerja guru dan pegawainya. Hal ini sejalan dengan pendapatnya Wether dan Davis yang menyebutkan bahwa beberapa faktor yang mempengaruhi kinerja adalah kemampuan $($ ability $=$ knowledge skill), dan faktor motivasi (motivation $=$ attitude situation $) .{ }^{4}$ Dengan demikian kinerja guru yang baik berikaiten dengan kepemimpinan yang baik pula.

Kepemimpinan kepala madrasah yang baik diharapkan dapat menghasilkan pendidikan yang berkualitas dan berdaya saing, karena hanya dengan pendidikan yang berkualitas peserta didik dapat menjadi manusia yang berkompeten, bermoral, dan berkarakter. Untuk merealisasikan pendidikan yang bermutu, dituntut penerapan program mutu yang terfokus pada upaya-upaya penyempurnaan mutu seluruh komponen dan kegiatan pendidikan di madrasah. ${ }^{5}$ salah satu komponen yang harus

2 Abdullah Munir, Menjadi Kepala Sekolah Efektif, (Jogjakarta: Ar-Ruzz Media, 2008), hal.

${ }^{3}$ Tim Penyusun Standar Kompetensi, Standar Kompetensi Kepala Sekolah TK, SD, SMP, SMA, SMK, dan SLB, (Yogyakarta: PustakaYustisia, 2007), hal. 102-103.

${ }^{4}$ Ibid., hal. 74.

${ }^{5}$ Wahjosumidjo, Kepemimpinan Kepala Sekolah Tinjauan Teoritik dan permasalahannya, (Jakarta: Raja Grafindo Persada, 2010), hal. 175-178. 
menjadi fokus utama kepala madrasah untuk disempurnakan adala kinerja guru, sehingga guru bisa memaksimalkan potensinya dalam mendidik dan membimbing peserta didik.

Berdasarkan beberapa uraian di atas, maka peneliti tertarik untuk melakukan suatu kajian tentang "Pola Kepemimpinan Kepala Madrasah dalam Meningkatkan kinerja guru di MI NW 02 Kembang Kerang Kecamatan Aikmel Kabupaten Lombok Timur.

\section{Kajian Pustaka}

\section{a. Kepemimpinan kepala madrasah}

Kepemimpinan merupakan salah satu faktor yang sangat berperan dalam organisasi, baik buruknya organisasi sering kali tergantung pada faktor pemimpin. Berbagai riset juga telah membuktikan bahwa faktor pemimpin memegang peranan penting dalam pengembangan organisasi. ${ }^{6}$ Peran pemimpin sudah Allah SWT tegaskan dalam Al-Qur'an Surah As-Sajdah ayat 24, yaitu sebagai berikut:

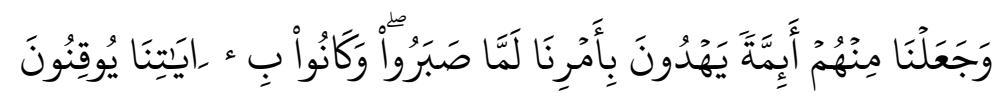

Artinya :

Dan Kami jadikan di antara mereka itu pemimpin-pemimpin yang memberi petunjuk dengan perintah Kami ketika mereka sabar. Dan adalah mereka meyakini ayat-ayat Kami.

Kandungan surah As-Sajdah ayat 24 tersebut menyatakan bahwa tugas utama pemimpin adalah memberi petuntuk ke jalan yang benar kepada bawahannya shingga organisasi atau lembaga yang dipimpin berjalan sebagaimana mestinya. Secara definisi kepemimpinan merupakan kegiatan untuk mempengaruhi orang-orang yang diarahkan terhadap pencapaian tujuan organisasi.7 Menurut Hersey dan Blanchard, berpendapat: "kepemimpinan adalah proses mempengaruhi

\footnotetext{
${ }^{6}$ Muhaimin, Manajemen Pendidikan: Aplikasinya dalam Menyusun Rencana Pengembangan Sekolah/Madrasah, (Jakarta: Kencana, 2011), hal. 29.

7 E. Mulyasa, Manajemen Berbasis Sekolah, (Bandung: Rosdakarya, 2002), hal. 107.
} 
aktivitas seseorang atau kelompok untuk mencapai tujuan dalam situasi tertentu. Berdasarkan definis tersebut maka kepemmpinan dalam madrasah dipegang oleh kepala madrasah.

Kepala madrasah adalah guru yang diberikan tugas tambahan untuk memimpin suatu sekolah yang diselenggarakan proses belajar-mengajar atau tempat terjadi interaksi antara guru yang memberi pelajaran dan murid yang menerima pelajaran. ${ }^{8}$ Dengan demikian ditarik kesimpulan bahwa, kepemimpinan kepala madrasah yaitu perilaku individu yang mampu memprakarsai pemikiran baru di dalam proses interaksi di lingkungan sekolah dengan melakukan perubahan atau penyesuaian tujuan, sasaran, konfigurasi, prosedur, input, proses atau output dari suatu sekolah sesuai dengan tuntutan perkembangan.

Kepala madrasah perlu menjalankan fungsi kepemimpinan secara operasional sesuai dengan kelembagaan. Adapun fungsi kepala madrasah menurut Roe dan Drake, yaitu:

a. Mendorong dan memotivasi staf untuk kinerja maksimal;

b. Mengembangkan staf secara realistik dan bertujuan dari akuntabillitas pengajaran (memonitor program pengajaran dan proses pengajaran);

c. Mengembangkan kerjasama dalam menilai prosedur bagi kelangsungan program untuk mengidentifikasi dan mengajukan alternatif untuk perbaikan kelemahan;

d. Bekerja dengan staf dalam mengembangkan dan melaksanakan evaluasi staf;

e. Bekerja dengan staf dalam menyusun rencana untuk evaluasi dan pelaporan kemajuan pelajar;

f. Menyediakan jaringan untuk keterlibatan masyarakat dalam operasional sekolah;

g. Mendorong kajian berkelanjutan terhadap kurikulum dan inovasi pengajaran serta memberikan pertolongan dan sumber daya untuk memajukan madrasah;

8 Jamal Ma'mur Asmani, Tips Menjadi Kepala Sekolah Profesional, (Jogjakarta: Diva Press, 
h. Menyediakan kepemimpinan untuk pelajar dalam membantu mereka mengembangkan diri penuh tanggung jawab;

i. Membangun pusat sumber belajar dan menata penggunaannya;

j. Mengembangkan kerjasama dengan staf dalam mengembangkan keprofesionalan yang dinamis dan program pelayanan pendidikan sendiri. ${ }^{9}$

\section{b. Kinerja guru}

Kata "kinerja" dalam bahasa Indonesia adalah terjemah dari kata dalam bahasa Inggris "performance" yang berarti (1) perkerjaan; perbuatan, atau (2) penampilan; pertunjukan. Sedangkan kinerja dalam istilah ilmu administrasi atau ilmu manajemen memiliki pengertian yang hampir sama yaitu ukuran kesuksesan dalam pencapaian tujuan yang telah ditetapkan (direncanakan) sebelumnya. ${ }^{10}$ Menurut Supardi kinerja merupakan suatu kegiatan yang dilakukan untuk melaksanakan, menyelesaikan tugas dan tanggung jawab sesuai dengan harapan dan tujuan yang telah ditetapkan.11 Dengan demikian kinerja guru dapat diartikan sebagai prestasi seorang guru yang diukur melalui standar yang telah ditentukan dan telah disepakati bersama ataupun kemungkinan-kemungkinan lain dalam suatu rencana pembelajaran yang sudah distandarisasikan melalui silabus berdasarkan ketetapan yang baku. Kinerja guru harus didikung dengan kualitas pendidikan dan kondisi kerja yang baik.

Soedijarto berpendapat "Untuk meningkatkan kualitas pendidikan, perlu adanya peningkatan kualitas rekrutmen, pelatihan, kondisi sosial, dan kondisi kerja guru, mereka membutuhkan pengetahuan yang tepat, keterampilan, karakter pribadi, profesionalitas dan motivasi sesuai dengan tujuan rekrutmen guru. ${ }^{12}$ Sedangkan menurut Hendarman bahwa kinerja guru dapat ditingkatkan melalui

${ }^{9}$ Syafaruddin, dkk., Kepemimpinan Pendidikan...., hal. 153.

10 Syaiful sagala, Manajemen Strategik dalam Peningkatan Mutu Pendidikan, (Bandung: Alfabeta, 2009), hal. 179.

${ }^{11}$ Supardi, Kinerja Guru, ( Jakarta: Grafindo, 2014 ), hal. 45

12 Soedijarto, Landasan dan arah Pendidikan Nasional,(Jakarta, Gramedia, 2008), hal. 160. 
kompetensi kepemimpinan Kepala Sekolah yang profesional. ${ }^{13}$ Berdasarkan beberapa pendapat di atas, dapat disimpulkan bahwa kepemimpinan kepala madrasah yang baik akan memberikan dampak yang baik pula terhadap peningkatan kinerja guru serta pegawai dalam lembaga pendidikan yang dikelolanya.

\section{Metode penelitian}

Penelitian ini merupakan penelitian kualitatif dengan desain studi kasus. Dalam mengkaji bagaimana pola kepemimpinan kepala madrasah dalam meningkatkan kinerja guru di MI NW 02 Kembang Kerang, desain studi kasus dipilih dengan beberapa alasan sebagai berikut: 1) studi kasus dapat memberikan informasi penting mengenai hubungan antara variabel serta proses-proses yang memerlukan penjelasan dan pemahaman yang lebih luas. 2) studi kasus memberikan kesempatan untuk memperoleh wawasan mengenai konsep-konsep dasar perilaku manusia. Dengan melalui penyelidikan peneliti dapat menemukan karakteristik dan hubungan yang mungkin tidak diharapkan dan diduga sebelumnya. 3) Studi kasus dapat menyajikan data-data dan temuan-temuan yang berguna sebagai dasar untuk membangun latar permasalahan bagi perencanaan penelitian yang lebih besar dan dalam rangka pengembangan ilmu-ilmu sosial. ${ }^{14}$

Data pada penelitian ini dikumpulkan menggunakan tehnik observasi, wawancara dan dokumentasi. Wawancara dilakukan dengan kepala Madrasah, guruguru dan pegawai MI NW 02 Kembang Kerang sebagai sumber data primer mengunakan wawancara terstruktur. Sedangkan tehnik observasi dan dokumentasi digunakan untuk mendapatkan data sekunder. Data yang sudah terkumpul kemudian dianalisis dengan tehnik analisis Miles and Huberman dengan langkah-langkah (1) reduksi data; (2) penyajian data; dan (3) penarikan kesimpulan. Keabsahan data hasil

\footnotetext{
${ }^{13}$ Hendarman, Revolosi Kinerja Kepala Sekolah,( Jakarta,Indeks,2015 ), hal. 7.

${ }^{14}$ Abdul Azis S.R., Memahami Fenomena melalui Studi Kasus; kumpulan Materi Pelatihan Metode Penelitian Kualitatif, (Surabaya: BMPTS Wilayah VII, 1988), hal. 6.
} 
analisis diuji dengan triangulasi teknik dan triangulasi sumber ketika mengumpulkan data.

\section{Pembahasan}

Pola kepemimpinan kepala madrasah dalam meningkatkan kinerja guru di MI NW 02 Kembang Kerang berhubungan dengan kinerja guru yang dilakukan guru dalam mengajar, mendidik, dan membimbing peserta didik menjadi anak-anak yang cerdas, mandiri, dan berakhlak mulia.

Kepala madrasah MI NW 02 Kembang Kerang dalam meningkatkan kinerja guru dimulai dari menerapkan sikap disiplin kepada guru, terutama terhadap kedisiplinan masuk dengan ketentuan harus masuk 20 menit sebelum siswa belajar di kelas terutama bagi guru piket dan guru kelas. Hal tersebut dimaksudkan agar bapak ibu guru dapat mengarahkan siswa untuk mempersiapkan lingkungan belajar yang bersih, rapi dan nyaman. Sebelum siswa masuk ke dalam kelas untuk belajar, siswa yang memiliki jam piket atau jadwal bersih terlebih dahulu membersihkan kelas dan lapangan agar lingkungan madrasah bersih dan sehat.

Kehadiran guru 20 menit sebelum jam pelajaran dimulai sangat ditekankan oleh kepala madrasah agar siswa dapat meneladani apa yang dilakukan guru setiap harinya, sehingga mereka lebih bersemangat untuk datang ke sekolah lebih pagi. Hal ini sesuai dengan pernyataan Oteng Sutrisno, bahwa kedisiplinan guru secara teratur dapat membimbing ke arah pertumbuhan kepribadian peserta didik secara sistematis dan pragmatis supaya sehingga mereka hidup sesuai dengan ajaran Islam dalam mencapai kebahagiaan di dunia dan akhirat. ${ }^{15}$ Di samping itu kepala madrasah sebagai contoh dan toladan bagi seluruh warga madrasah selalu berupaya datang tepat waktu dan selalu menghimbau kepada Bapak dan Ibu guru agar guru ketika masuk kelas atau pun keluar kelas sesuai dengan jadwal yang telah ditetapkan.

Kepala madrasah dalam mengupayakan sikap disiplin bagi para guru di MI NW 02 Kembang Kerang dilakukan dengan memberi contoh tauladan kepada seluruh warga

15 Oteng Sutrisno, Administrasi Pendidikan Dasar Teoritis dan Praktek Professional, (Bandung: Angkasa, 1985), 97. 
madrasah. Hal tersebut dilakukan untuk memberi pembiasaan kepada guru dalam upaya meningkatkan kedisiplinan. Menurut Pidarta, disiplin dapat membuat seorang guru tidak merasa dipaksa dalam mentaati peraturan dan menjalankan tugasnya sebagai pendidik, akan tetapi dapat memerntah diri untuk melakukan sesuatu dengan penuh tanggung jawab. ${ }^{16}$

Dari program yang ditetapkan oleh kepala madrasah di MI NW 02 Kembang Kerang menunjukkan bahwa kepemimpinan yang dilakukan kepala madrasah dalam upaya meningkatkan kinerja guru di MI NW 02 Kembang Kerang memiliki perencanaan yang cukup baik. Akan tetapi, perencanaan yang baik tanpa upaya untuk melaksanakan program yang telah dibuat tidak akan memberikan hasil yang maksimal. Maka di sinilah peran kepala madrasah sebagai pengontrol kegiatan atau pengawas di madrasah. Oleh karena itu, kepala madrasah tidak segan-segan berdiskusi dengan guru dan selalu mengingatkan tentang tugas dan tanggung jawab sebagai guru, terutama bagi semua guru-guru sertifikasi agar lebih aktif, baik di dalam proses pembelajaran atau pun dalam melengkapi administrasi belajar mengajar. Menurut Herk dalam Sulistyorini mengatakan bahwa seorang kepala sekolah sebagai seorang administrator tidak boleh memandang guru sebagai bawahannya, melainkan sebagai teman sejawat. ${ }^{17}$ sehingga dalam memberikan arahan kepada guru tentang kelengkapan administrasi mengajar kepala madrasah berupaya memberikan saran kepada para guru.

Untuk meningkatkan kinerja guru dalam proses pembelajaran di kelas, kepala madrasah mewajibkan para guru memiliki perangkat pembelajaran dengan mengacu pada standar kurikulum yang berlaku. Perangkat pembelajaran yang dibuat oleh guru meliputi program tahunan, program semester, analisis program semester, rencana pelaksanaan pembelajaran, dan rencana evaluasi belajar bagi peserta didik. Akan tetapi, kurangnya media belajar atau alat peraga menyebabkan guru menjadi satu-satunya

\footnotetext{
${ }^{16}$ Made Pidarta, Pemikiran tentang Supervisi Pendidikan, (Jakarta: Bumi Aksara, 1992), hal. 56

${ }^{17}$ Sulistyorini, Kepemimpinan Kepala Sekolah dalam Pengembangan Sekolah Dasar, (Jember: CSS, 2008), hal. 99.
} 
sumber belajar, dan siswa kurang berperan aktif dalam proses pembelajaran. Kondisi ini menjadi kendala bagi guru dalam memaksimalkan kegiatan pembelajaran di kelas.

Selanjutnya untuk tetap memaksimalkan kinerja guru, baik di dalam kelas maupun di luar kelas kepala madrasah selalu menyiapkan waktu untuk berkomunikasi secara terbuka dan berdiskusi dengan para guru, agar setiap persoalan dan kendala yang dihadapi guru dalam proses pembelajaran dapat diselesaikan dengan baik. Menurut Siswanto, kinerja guru yang baik tergambar pada penampilan mereka menjadi guru. Artinya guru mampu mengelola pengajaran di dalam kelas dan mendidik siswa di luar kelas dengan sebaik-baiknya.18 Dan jika suatu permasalahan berhubungan dengan program jangka panjang, maka kepala madrasah mengadakan pertemuan pertemuan secara aktif dengan warga madrasah.

Kepala madrasah senantiasa memberikan motivasi agar para guru selalu bersemangat mengajar dan membimbing peserta didik sehingga guru di MI NW 02 Kembang Kerang memaksimalkan kinerjanya, Sebagai seorang motivator kepala madrasah selalu memberi bimbingan dan arahan kepada seluruh tenaga pendidik di MI NW 02 Kembang Kerang untuk senantiasa meningkatkan profesionalisme guru, mengajar dengan tulus dan selalu bekerja dengan sungguh-sungguh, karena sebagai guru yang mengajar di bawah naungan yayasan guru madrasah adalah guru-guru yang diberi amanat oleh masyarakat secara umum sekaligus oleh pemerintah. Menurut Mulyasa, kepala madrasah harus memiliki strategi yang tepat untuk memberikan motivasi kepada para tenaga kependidikan dalam melakukan berbagai tugas dan fungsinya. ${ }^{19}$

Menjadi guru yang profesional di bidangnya adalah suatu tuntutan yang harus dijalankan oleh setiap guru. Mereka harus bekerja keras dan bekerja ikhlas dalam mendidik anak-anak bangsa menjadi anak-anak yang cerdas, mandiri dan berakhlaqul karimah. Akan tetapi tugas yang mulia ini tidak serta merta dapat dijalankan dengan

${ }^{18}$ Siswanto Sastrohardiwiryo, Manajemen tenaga kerja Indonesia, Pendekatan Administratif dan Operasional, (Jakarta: Bumi Aksara, 20030, HAL. 234.

19 E. Mulyasa, Manajemen Berbasis Sekolah, (Bandung: Rosdakarya, 2002), hal. 120. 
mudah dan lancar sesuai dengan harapan melainkan selalu ada hambatan dan kendalakendala yang dihadapi oleh guru maupun peserta didik.

Di antara kendala-kendala yang dihadapi guru dan siswa adalah lokasi sebagian besar siswa dan guru yang cukup jauh dari madrasah. Keadaan ini sering menjadi kendala bagi kepala madrasah dalam menerapkan kedisiplinan guru dan siswa. Di samping itu, sumber dana madrasah yang minim, dan hanya mengandalkan dana BOS (Bantuan Operasional Sekolah) tidaklah cukup memadai untuk melengkapai berbagai kebutuhan madrasah termasuk untuk pengadaan media belajar yang cukup bagi aktivitas siswa dan sumber-sumber belajar yang cukup bagi guru dan siswa. Oleh karena itu, salah satu upaya yang dilakukan kepala madrasah dalam memaksimalkan kinerja guru di MI NW 02 Kembang Kerang adalah dengan memberikan semangat, motivasi, dan selalu berkomunikasi dengan baik agar semua kekurangan-kekurangan dalam proses belajar mengajar dapat diatasi.

\section{Kesimpulan}

Berdasarkan pada hasil penelitian dan pembahasan tentang kepemimpinan kepala madrasah dalam meningkatkan kinerja guru di MI NW 02 Kembang Kerang, maka dapat diambil kesimpulan sebagai berikut:

1. Pola Kepemimpinan yang dijalankan kepala madrasah di MI NW 02 Kembang Kerang tergolong kepada tipe kepemimpinan demokratis dimana kepala madrasah selalu mengadakan musyawarah kepada seluruh dewan guru, staf dan tata usaha dalam menetapkan setiap keputusan yang akan diambil.

2. Kepala madrasah dalam meningkatkan kinerja guru di MI NW 02 Kembang Kerang telah melakukan beberapa upaya, antara lain; a. menanmkan sikap disiplin, b. pembinaan dan supervisi, c. meningkatkan sumber daya dan profesionalisme guru, d. memberikan motivasi, dan e. menyediakan fasilitas yang memadai bagi guru.

Faktor pendukung kepemimpinan kepala madrasah dalam meningkatkan kinerja guru di MI NW 02 Kembang Kerang, meliputi; a. hubungan yang harmonis antara kepal madrasah dan guru, dan b. adanya motivasi yang kuat dari guru. 
Sedangkan yang menjadi faktor penghambat bagi kepemimpinan kepala madrasah dalam meningkatkan kinerja guru di MI NW 02 Kembang Kerang meliputi; a. kurangnya sarana dan prasarana belajar, dan b. tempat tinggal guru dan siswa yang jauh dari madrasah.

\section{Daftar Referensi}

Asmani, Jamal M., Tips Menjadi Kepala Sekolah Profesional, (Jogjakarta: Diva Press, 2012).

Azis S.R., A., Memahami Fenomena melalui Studi Kasus; kumpulan Materi Pelatihan Metode Penelitian Kualitatif, (Surabaya: BMPTS Wilayah VII, 1988).

Hendarman, Revolosi Kinerja Kepala Sekolah, ( Jakarta: Indeks, 2015 ).

Muhaimin, Manajemen Pendidikan: Aplikasinya dalam Menyusun Rencana Pengembangan Sekolah/Madrasah, (Jakarta: Kencana, 2011).

Mulyasa, E., Manajemen Berbasis Sekolah, (Bandung: Rosdakarya, 2002).

Munir, A., Menjadi Kepala Sekolah Efektif, (Jogjakarta: Ar-Ruzz Media, 2008)

Pidarta, M., Pemikiran tentang Supervisi Pendidikan, (Jakarta: Bumi Aksara, 1992).

Sagala, S., Manajemen Strategik dalam Peningkatan Mutu Pendidikan, (Bandung: Alfabeta, 2009).

Sastrohardiwiryo, S., Manajemen tenaga kerja Indonesia, Pendekatan Administratif dan Operasional, (Jakarta: Bumi Aksara, 2003).

Soedijarto, Landasan dan arah Pendidikan Nasional,(Jakarta: Gramedia, 2008).

Sulistyorini, Kepemimpinan Kepala Sekolah dalam Pengembangan Sekolah Dasar, (Jember: CSS, 2008).

Supardi, Kinerja Guru, ( Jakarta: Grafindo, 2014 ).

Sutrisno, O., Administrasi Pendidikan Dasar Teoritis dan Praktek Professional, (Bandung: Angkasa, 1985).

Syafaruddin, dkk., Kepemimpinan Pendidikan Kontemporer, (Bandung: Citapustaka Media, 2015). 
Jurnal Manajemen dan Budaya STAI Darul Kamal NW Kembang kerang

Volume 1 No 1 Tahun 2021

P-ISSN : 0000-0000

E-ISSN : 2774-6704

https://journal.staidk.ac.id/index.php/mdb

Tim Penyusun Standar Kompetensi, Standar Kompetensi Kepala Sekolah TK, SD, SMP, SMA, SMK, dan SLB, (Yogyakarta: PustakaYustisia, 2007).

Wahjosumdjo, Kepemimpinan Kepala Sekolah, (Jakarta: Raja Grafindo Persada 2007).

Wahjosumidjo, Kepemimpinan Kepala Sekolah Tinjauan Teoritik dan permasalahannya, (Jakarta: Raja Grafindo Persada, 2010). 